\title{
Certain and potential earthquake-induced landslides in Vrancea seismic region
}

\author{
Mihai Micu \\ Institute of Geography \\ Romanian Academy \\ Bucharest, Romania \\ mikkutu@yahoo.com
}

\author{
Hans-Balder Havenith \\ Department of Geology - Georisks and Environment \\ University of Liege \\ Liege, Belgium \\ HB.Havenith@ulg.ac.be
}

\author{
Dan Bălteanu \\ Institute of Geography \\ Romanian Academy \\ Bucharest, Romania \\ igar@geoinst.ro
}

\begin{abstract}
Earthquakes are representing across Earth's seismically-active regions a major trigger of small-to-large size landslides. Occurred in form of coseismic or postseismic failures, these processes are controlling the slope denudation, inducing in the mean time significant impacts on fluvial morphology through intense slope-channel coupling. Relict, dormant or active forms resembling like earthquake-induced ones are numerous in the Vrancea seismic region (Curvature sector of the South-Eastern Carpathians), at least from a morphological point of view. The purpose of this paper is to outline the morphogenetic framework of such high magnitude and low frequency processes on the basis of several case-studies. The Slon, Zăbala, Zâmbroaia and Mlăjet landslides are known as being triggered by the 1940 and 1977 earthquakes. Two other landslides are showing a very high potential of being as well caused (immediate or delayed) by earthquakes: the deep-seated Balta rock slump (92 ha, 60-80 m thick), a potential co-seismic landslide and the Paltineni debris flow ( $22 \mathrm{ha}, 30-40 \mathrm{~m}$ thick), highly likely the result of postseismic evolution of a seismically-triggered slump. The two processes are discussed in terms of morphology (assessed through digital stereographic interpretation of aerial photos and LiDAR-derived hillshade DEM) and internal structure (based on ERT and V/R soundings). The Factor of Safety calculation (Bishop method) analysis showed that, at least for the Balta landslide, an additional driving moment from seismic acceleration was necessary to trigger the movement. Such an approach is important within a multi-hazard risk preparedness and prevention framework, allowing us to define different levels of seismic shaking (in combination with variable climatic background conditions) and the related return periods.
\end{abstract}

\author{
Alexandru Onaca \\ Geography Department \\ West University of Timisoara \\ Timisoara, Romania \\ alexandru.onaca@e-uvt.ro
}

Anne-Sophie Mreyen
Department of Geology - Georisks and Environment
University of Liege
Liege, Belgium
anne-sophie.mreyen@rwth-aachen.de

\author{
Carmen Cioflan \\ Engineering Seismology Laboratory \\ National Institute for Earth Physics \\ Magurele, Romania \\ cioflan@infp.ro
}

Keywords- landslides; earthquakes; Vrancea seismic
region

\section{INTRODUCTION}

In seismically-active regions, earthquakes are representing a major cause of large, deep-seated landslides. The Vrancea Seismic Region (Curvature sector of the Eastern Romanian Carpathians) represents the most active intermediate-depth (focal depth 60-200 km) earthquake province of Europe. During the last 300 years, the region featured 12 earthquakes with $\mathrm{M}>7$, among which four events with magnitude above (and equal to) 7.5 and three between 7.7 and 7.9. Vrancea earthquakes are responsible for causing numerous geohazards, such as ground fracturing, groundwater level disturbances and possible deep-seated landslide occurrence (in form of rock slumps, rock-block slides, rock falls or rock avalanches). The purpose of this study is to outline the morphogenetic framework of such high magnitude and low frequency processes on the basis of two case-studies: Balta rock slide and Paltineni debris flow (Fig.1).

\section{DATA AND METHODS}

Landslides were assessed through field mapping backed-up by digital stereographic photo interpretation, using color aerial orthophotos (cell size $2 \mathrm{~m}$, resample from an original $0.5 \mathrm{~m}$ ) from the year 2005 (ANCPI Bucharest). DEM (cell size $20 \mathrm{~m}$ for the morphometric derivates, $2 \mathrm{~m}$ for the anaglyph interpretation) was obtained from linear 
interpolation of topographic contour lines (5 m interval) derived from DTM (Military Topographic Direction) 1:25000 topomaps (1960-1980). The lithological information was derived from the geologic maps (1:200000) of the Geological Institute of Romania. Earthquake data are in accordance with the ROMPLUS catalogue (National Institute for Earth Physics).
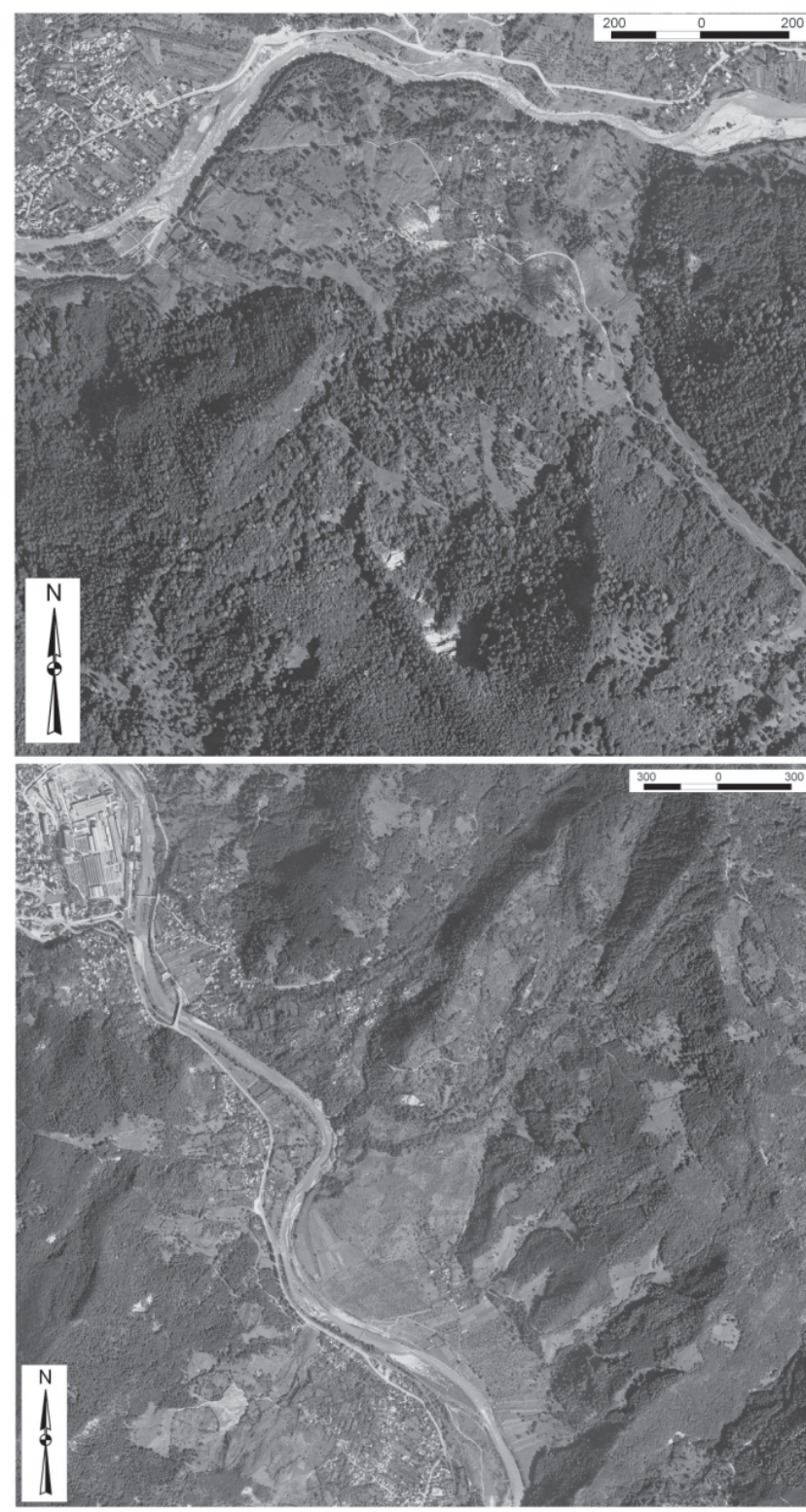

Fig. 1. The courses of Bâsca Rozilei (above) and Buzău (below) rivers, modified by the Balta and Paltineni earthquake-induced landslides (aerial photo, 2005, ANCPI)

ERT profiles consist of 2D electrical resistivity tomographies along four alignments of $395 \mathrm{~m}$ and one of $590 \mathrm{~m}$ long (resistivity data processed with the RES2DINV software from GEOTOMO). H/V method consists out of ambient noise measurements in order to determine the soil resonance frequency through microseismic spectral analysis. Factor of Safety for Balta rock slide was calculated using Bishop slope model. An apriori assessment of Simplified Newmark displacement (Newmark 1965, adapted for GIS analyses including Arias Intensity by Jibson et al.,1998, Miles and Ho,1999; Arias Intensity - m/s - was calculated for 1940 M7.7 earthquake and includes curvature amplification; critical acceleration evaluated for average geology: cohesion=100 $\mathrm{kPa}$, friction $=32^{\circ}$, density $=2200 \mathrm{~kg} / \mathrm{m}^{3}$ ) was provided by Micu et al., 2015.

\section{Preliminary Results}

The co-seismic landslide hypothesis arguments for Balta landslide (Fig.2) consists of: head scarp close to the ridge top and far away from the river; fault line vicinity; anti-dip slope; primary rotational slide not connected with channel processes. The field measurements and assessment outlined: the existence of a complex (rock slump, debris slide) landslide; a relict/dormant stage of activity; reactivations along the toe due to river undercut; total surface of 92 ha and above 70-80 m max. thickness of the landslide deposit; cause of an ancient landslide dam on Bâsca Rozilei River (river course changed); 10 households affected by creep-slide reactivations.

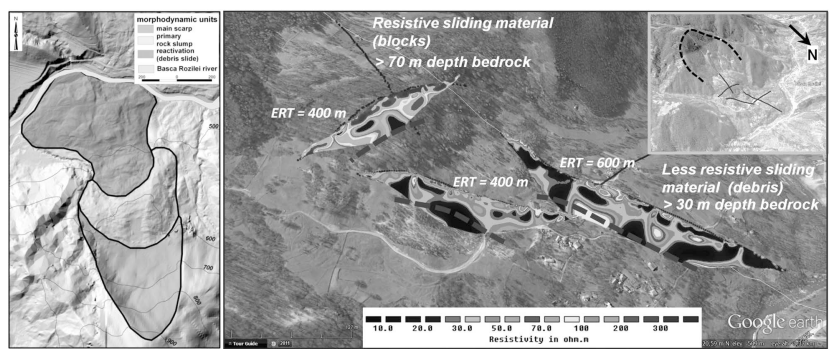

Fig. 2. Balta landslide

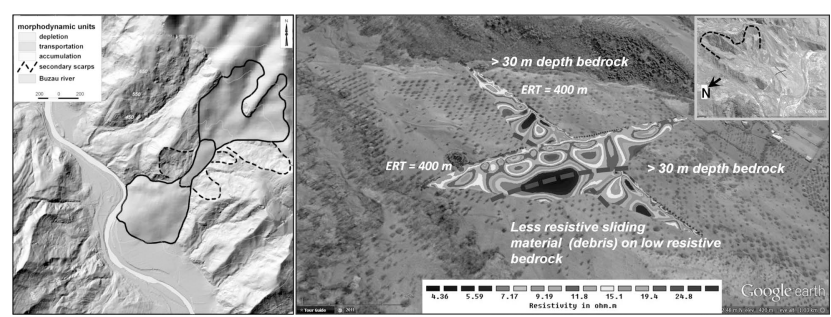

Fig. 3. Păltineni landslide

The earthquake-induced (potentially combined with precipitation) landslide hypothesis arguments for Păltineni landslide (Fig.3) consists of: sudden change (almost 90 degrees) of Buzau river flowing direction towards west with more than $400 \mathrm{~m}$ due to a sudden displacement of a large, compact mass of debris covering almost 25 hectares (50-60 m max. thickness). The field measurements and assessment outlined: a complex (rock slump, debris flow) landslide; a relict/dormant stage of activity; numerous toe reactivations (active river undercut); 80 ha surface and above 50-60 m max. thickness of the landslide deposit; river morphology major impact: Buzau river pushed by 400-450 m; active river undercut may cause large reactivations (landslide dam).

\section{CONCLUSIONS AND PERSPECTIVES}

Balta represents a complex landslide triggered by an above M 7.5 intermediate-focus earthquake. Balta primary 3D model (Fig.4) highlights the different processes (initial rock slump and subsequently-reactivated translational debris slide), backing-up the hypothesis of earthquake trigger. Paltineni represents a debris flow (highly likely) resulting out of the post-seismic evolution of a seismicallytriggered rock slump. Intermediate-deep earthquakes from 
Vrancea seismic region can trigger both co and postseismic massive, deep-seated slope failures within a relatively smooth relief (compared to the high mountain regions in Central Asia), considering possible geologic and topographic site-effects. The perspectives of this study are consistent: reconstruction of regional seismic history through paleo-seismic landslides; a better accelerometer instrumentation and monitoring of slopes, resulting in a more detailed understanding of the geologic and topographic potential accelerations; definition of different levels of seismic shaking (in combination with variable climatic background conditions) and the related return periods, as a proxi for multi-hazard risk preparedness and prevention frameworks.

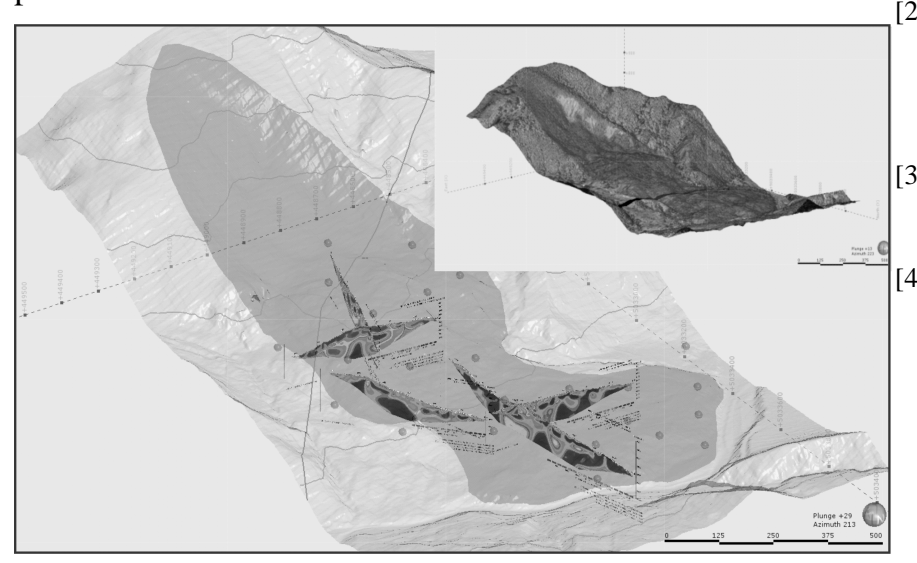

Fig. 4. 3D model of Balta landslide

\section{ACKNOWLEDGMENT}

This work has been performed within the AR-WBI Project Evaluation des risqué long-termes lies aux mouvements de masse declenches par les seismes dans la region de Vrancea and includes partial results from FP7 MC-ITN CHANGES and FP7 IncREO.

\section{REFERENCES}

[1] R.W. Jibson, E.L. Harp, and J.A. Michael "A method for producing digital probabilistic seismic landslide hazard maps-an example from the Los Angeles, California, area”, U.S. Geological Survey Open-File Report 98-113. 17 p., 2 pl., 1998.

[2] M. Micu, D. Balteanu, C. Ionescu, H.B. Havenith, M. Radulian, C. van Westen, M. Damen, and M. Jurchescu “A preliminary regional assessment of earthquake-induced landslide susceptibility for Vrancea Seismic Region”, Geophysical Research Abstracts, Vol. 17, EGU2015-12524, 2015.

[3] S.B. Miles and C.L. Ho "Rigorous landslide hazard zonation using Newmark's method and stochastic ground motion simulation”, Soil Dynamics and Earthquake Engineering, 18, pp. 305-323, 1999.

[4] N.M. Newmark, "Effects of earthquakes on dams and embankments”. Geotechnique, 15, pp. 139-160, 1965. 